\title{
Reproductive biology of Vatica venulosa Blume (Dipterocarpaceae)
}

\author{
AULIA HASAN WIDJAYA ${ }^{1,2}$, DIAN LATIFAH ${ }^{2}$, KATE A. HARDWICK ${ }^{3}$, M. RAHMAD SUHARTANTO ${ }^{4}$, \\ ENDAH RETNO PALUPI ${ }^{4, \vartheta}$ \\ ${ }^{1}$ Seed Science and Technology Study Program, Graduates School, IPB University. J1. Meranti, Kampus IPB Darmaga, Bogor 16680 Indonesia \\ ${ }^{2}$ Research Center for Plant Conservation and Botanic Gardens, National Research and Innovation Agency. Jl. Ir. H. Juanda No. 13, Bogor 16003, West \\ Java, Indonesia \\ ${ }^{3}$ Royal Botanic Gardens Kew. Wakehurst Place, Ardingly West Sussex, RH17 6TN, UK \\ ${ }^{4}$ Department of Agronomy and Horticulture, Faculty of Agriculture, IPB University. Jl. Meranti, Kampus IPB Darmaga, Bogor 16680 Indonesia. \\ Tel.: +62-251-8629354, Fax.: +62-251-8629352,`email: erpalupi@ yahoo.co.id
}

Manuscript received: 27 July 2021. Revision accepted: 23 September 2021.

\begin{abstract}
Widjaya AH, Latifah D, Hardwick KA, Suhartanto MR, Palupi ER. 2021. Reproductive biology of Vatica venulosa Blume (Dipterocarpaceae). Biodiversitas 22: 4327-4337. Vatica venulosa Blume is categorized as Critically Endangered A1c ver 2.3, according to the IUCN Red List. A study of the reproductive biology of $V$. venulosa Blume was carried out in August 2019-February 2020 at the Research Center for Plant Conservation and Botanic Gardens, Bogor, Indonesia. The research observed flower morphology, flower development, type of pollination, fruit and seed structures. $V$. venulosa is categorized as having a sub-annual flowering pattern. The flowering phenology of $V$. venulosa from flower bud emergence until fruit senescence takes about 6 months. The flower is hermaphroditic, with position of the pistil is higher/longer than the stamen; and pollen was released prior to stigma being receptive (protandrous). V. venulosa is a cross-pollinated plant, the flower visitors are insect nymphs of Thrips sp. (Thysanoptera: Thripidae), which are white and 1-1.5 mm in size. The percentage of blooming flowers was 32.3-37.9\%, fruit set 10.9\%-12.6\%. Seed physiological maturity is reached at the age of 101 $\pm 3-106 \pm 3$ days after the flowers bloom when the wings are yellow green or green orange in color. $V$. venulosa seed is a non endospermous seed, and the cotyledons are composed mainly of small clumps of starch, being $42.5 \%$ carbohydrate.
\end{abstract}

Keywords: Critically endangered, flower visitors, fruit set, heteromorphic, physiological maturation, protandrous

Abbreviations: BBCH: Biologische Bundesanstalt Bundessortenamt und Chemische Industrie; BBG: Botanic Gardens; BGG: Blue Green Group; DAA: days after anthesisGBG: Green Blue Group; GC: germination capacity; GG: Green Group; GOG: Green Orange Group; IUCN: International Union for Conservation of Nature and Natural Resources; MC: moisture content; MGP: maximum growth potential; PF: protected forest; VI: vigor index; YGG: Yellow Green Group

\section{INTRODUCTION}

Vatica venulosa Blume (Dipterocarpaceae) is one of the rare plant species listed in the red list of threatened species issued by the International Union for Conservation of Nature and Natural Resources (IUCN) in 2019 under the status of Critically Endangered A1c ver 2.3 (Ashton 1998), due to population decline in natural habitat caused by land use alteration and habitat degradation (Daisuke 2013). V. venulosa is a tree that grows in tropical forests, lowland dipterocarp forests, riparian and along streams (El Taguri and Latiff 2016). In Indonesia $V$. venulosa is found in Sumatera and Kalimantan (POWO 2020).

In general, Dipterocarpaceae species have a flowering interval of 2-10 years (Chechina and Hamann 2019). Flowering pattern of Dipterocarpaceae in Bukit Barisan Selatan National Park Forest (BBSNP), Sumatera shows peak flowering in March to July every year, and fruiting period during one to two months following the main flowering period (Winarni et al. 2016). However, Suhaida et al. (2018) reported that Vatica yeechongii (Dipterocarpaceae) in Tekala River-Sungai Lalang Selangor Malaysia flowers and produces fruit annually, so as those in Setul, Malaysia. Moreover some trees are able to flower twice a year during February-March and September-November. Kurten et al. (2017) observed the dipterocarp forest during the 2 years flowering season in Khao Chong Forest-Thailand and reported that flowering patterns of the 294 plant species could be grouped into 4 types, i.e. continual $3.4 \%$, supra annual $45 \%$, annual $44.3 \%$, and sub annual $7.4 \%$.

Suhaida et al. (2018) reported that the flowering pattern of $V$. yeechongii is sub annual and the flower is selfincompatible, therefore seeds are produced from cross pollination. Apidae is the common flower visitors and possibly the effective pollinators due to their ability to carry pollen load. Fruit maturation took 21-22 weeks after anthesis, which falls in July-August and January-February. The flowers of $V$. yeechongii are protandrous, i.e. pollen matures prior to stigma receptivity.

Field study and conservation of Dipterocarpaceae species is necessary as many of these plants are endemic, rare and even threatened with extinction due to forest degradation by land clearing for plantations or cultivation. Information related to the reproductive cycle, including the flowering pattern and the time to fruit and seed 
physiological maturity are required to support conservation of the germplasm.

Germplasm conservation requires seed with high viability and vigor which can be obtained from timely harvested fruit, i.e. after reaching physiological maturity. Therefore, reproductive biology and determination of the physiological maturity of $V$. venulosa seeds need to be studied to support the species' conservation.

\section{MATERIALS AND METHODS}

Observations on flowering and fruiting of the Vatica venulosa were carried out from August 2019 till February 2020, which covered one flowering season, at the Research Center for Plant Conservation and Botanic Gardens (BBG), Bogor, Indonesia. The materials used were two $V$. venulosa trees that were 15 years old, about $8 \mathrm{~m}$ high (collection number XXIV.A.235). These trees were planted in 2005 from seeds originated from Berbak National Park, Jambi, Sumatra (5-20 m asl), and started flowering in 2013. The reproductive biology of $V$. venulosa was studied by observing flower morphology, flower and fruit development from flower buds to fruit maturity, pollination syndrome, and seed structure. As comparison flowering of $V$. venulosa in Bangka-Belitung Islands off the east coast of Sumatra was also observed to investigate their reproductive biology in its natural habitat.

\section{Procedures}

\section{Flowering phenology}

Flower samples were taken from two trees, from four cardinal directions on each tree (north, south, east, west), with 10 inflorescences sampled from each direction (a total of 80 inflorescences). The observed variables included bud and flower developmental phases, the type of inflorescence, the location of the inflorescences, the average number of flowers per inflorescence, and flower structure (the number of petals, stamens, ovules per ovary, and the type of pistil) (Djuita 2016).

\section{Bud and flower development}

The development of $V$. venulosa flowers was observed based on the $\mathrm{BBCH}$ (Biologische Bundesanstalt
Bundessortenamt und Chemische Industrie) Scale, Germany. Observation was carried out on 40 flowers from each cardinal direction. The $\mathrm{BBCH}$ scale used for $V$. venulosa refers to the category of stone fruits (e.g. Prunus spp) which is divided into 8 phases (phase 0-phase 9, excluding phases 2 and 4), from initiation of leaf and flower buds through to maturity and senescence of the fruit (Table 1) (Meier 2018).

\section{Pollination system}

Fruit set from self and open pollination was observed to determine the pollination syndrome of the species. Ten inflorescences on each cardinal direction (total 40 inflorescences per tree) were covered by a cloth bag at flower bud stage to observe if autonomous or control selfpollination would resulted in fruit set. The cloth bag was removed a week after pollination. Some other inflorescences were kept open to be pollinated by insects and/or wind. The period from flowering to fruit initiation and fruit maturation were observed.

\section{Fruit and seeds}

Fruit set and seed set were observed beginning from pollination (at anthesis) until the fruits were at optimal maturity for harvest. About 418 flowers from 80 inflorescences were observed. Fruit set was ascribed as the percentage of blooming flowers that developed into mature fruits, whereas seed set was the percentage of ovuls that developed into viable seed. The number of ovuls per ovary was the average for ovaries from ten flowers. To determine the reproductive success, the number of flower buds per inflorescence, the number of blooming flowers per inflorescence and the number of fruit per inflorescence were observed.

The seed viability and seed vigor are at the highest at physiological maturity. To determine the seed physiological maturity fruits were harvested at four categories, i.e. when wings and pericarp were green (maturity stage 1), brown wings with green pericarp (maturity stage 2), brown wings with brown pericarp (maturity stage 3), and light brown wings and brown pericarp (maturity stage 4 ).

Table 1. Development phases of Vatica venulosa adopted from BBCH-scale

\begin{tabular}{|c|c|c|}
\hline Phase & Code & Description \\
\hline $\begin{array}{l}\text { Spouting/bud } \\
\text { development }\end{array}$ & 0 & $\begin{array}{l}\text { This phase starts from the emergence of leaf buds and the inflorescences which are thicker } \\
\text { covered with dark brown ridges. Early leaf buds, are visible light brown protrusions, and a bulge } \\
\text { with a light colored tip. The tips of the noble green leaves are visible. }\end{array}$ \\
\hline Leaf development & 1 & Leaf development phase is characterized by young shoots visible with the fully expanded first leaves. \\
\hline Shoot development & 3 & Early shoot development is characterized by visible bud development, shoot length from $20 \%$ to $90 \%$. \\
\hline Inflorescence emergence & 5 & From the appearance of inflorescences until before the flowers bloom. \\
\hline Flowering & 6 & From blooming to the end of flowering (all petals fall). \\
\hline Development of fruit & 7 & Begins to develop ovaries until fruit is $90 \%$ of final size. \\
\hline Maturity of fruit and seed & 8 & Starting from colored fruit until the fruit is mature for harvest. \\
\hline Fruit senescence & 9 & Starting from mature fruit until the fruit falls of the tree. \\
\hline
\end{tabular}


The seeds then were germinated, and the viability as well as the vigor were observed. Germination capacity (variable of seed viability) is the percentage of seeds that develop into normal seedlings within testing period (first count at 23 day after germination/DAG and final count at 33 DAG). Whilst vigor index (variable of seed vigor) is the percentage of seeds that develop into normal seedlings at 23 DAG (first count). Once the stage of physiological maturity was determined then the fruit characters related to the stage was defined as indicators for harvest. Observation of the seed structure was carried out to determine the proportion of the embryo and the cotyledons the whole seed.

\section{Data analysis}

Data was analized based on F test whenever appropriate, or else average with standard deviation (SD) was used.

\section{RESULTS AND DISCUSSION}

\section{Flower phenology}

The 15-year-old trees (number collection XXIV.A.235two individuals) flowered between August-September, while the fruiting season was between January-February. However, it was found that the trees started flowering again between February-March, at the end of previous fruiting season, and the fruits matured between June-July. Although detailed observation was carried out only on one flowering season, but evidently the flowering pattern of $V$. venulosa is sub annual (Table 2).

Flowering of $V$. venulosa starts from the top of the tree and continues to the lower part of the branch and lastly flowers on the lower part of the branch. Inflorescences that appear on the branches, twigs and axillary leaves are arranged in a series of inflorescences in the form of a panicle. One $V$. venulosa inflorescence (Figure 1.A) consists of 1-20 flower buds. The flower buds are green, then turn into purple, yellowish purple, and creamy yellow until the flower blooms. Vatica venulosa flower formula adopted from Ronse De Craene (2014):
* $\mathrm{K}(5)$ C5 A 5+10 $\underline{\mathrm{G}}(3)$ Vatica venulosa Blume (Dipterocarpaceae)

* Polysymmetric (actinomorphic)

K calyx (sepals)

C corolla

A androecium (stamens)

G gynoecium (carpels): superior $(\underline{\mathrm{G}})$

Vatica venulosa flowers (Figure 1.B) including complete flowers, are arranged in polysymmetry, with 5 petals, 5 sepals and 15 stamens arranged in 2 strata, strata 1 (top) consisting of 5 stamens (long) and strata 2 (bottom) consisting of 10 stamens (short). The anthers split longitudinally, with attachment to the stalk was at the middle of the ridge (dorsifixed), the connective type is modified into a claw-shaped appendage. The appendage is an additional structure that is a modification of a part of an organ (usually elongated or curved). The stigma is lobe shaped, and divided into three parts with a hole in the middle. The pumpkin shaped ovary is located superiorly, with three loci, and six ovules, with axilar type placentation (Figure 2).

Flowering begins with the emergence of brownish shoots in the axillary leaves with sharp shoot tips (Figure 3.A). The appearance of flower buds (Figure 3.B) is marked with a brown to yellowish and swollen tip. The Vatica venulosa inflorescence is arranged in a panicle with 1-20 flowers (Figure 3.C). The development from the inflorescence buds until the first flower blooms took 7-9 days. In one inflorescence, the flowers bloomed from tip to base and last for 1-10 days (Figure 3.D, 4.E).

Vatica venulosa flowers bloomed from 05.00-06.00 $\mathrm{AM}$ and last for 1 day. After the flowers bloomed, the stamens ripened at 05.00-08.00 AM, marked by the initiation of fragrance of the flower, prior to ripening of the pistil, which occurred at 09.00-10.00 AM, marked by a slimy stigma. Slower ripening of the pistil and its position which was higher than the stamen, strongly indicated that $V$. venulosa is a cross pollinating plant. The petals from pollinated flowers fell off 1-3 days after blooming, while those which were not pollinated fell off within 1 day after blooming.

Table 2. Flowering phenology of 15-year-old Vatica venulosa at the Research Center for Plant Conservation and Botanic Gardens, Bogor, Indonesia

\begin{tabular}{|c|c|c|c|c|c|c|c|c|c|c|c|c|}
\hline Phase & Jan & Feb & Mar & Apr & May & Jun & Jul & Aug & Sep & Oct & Nov & Dec \\
\hline Spouting/bud development & & & & & & & - & & & & & \\
\hline Leaf development & & & & & & & & - & & & & \\
\hline Shoot development & & & & & & & & - & & & & \\
\hline Inflorescence emergence & & & & & & & & & & & & \\
\hline Flowering & & & & & & & & & 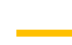 & & & \\
\hline Development of fruit & & & & & & & & & & & & \\
\hline Maturity of fruit and seed & & & & & & & & & & & & - \\
\hline Fruit senescence & & 一 & & & & & & & & & & \\
\hline Flowering season & & & & & & & & & & & & \\
\hline Fruiting season & & & - & & & & & 工 & & & & \\
\hline
\end{tabular}




\section{Flower development}

The flower development of the $8 \mathrm{~m}$ height $V$. venulosa trees (Figure 4.A) was divided into 8 phases $(\mathrm{BBCH})$, started with shoot development (phase 0) when light brown protrusions emerged from the twigs, followed by leaf tips, and leaf axils until the appearance of light brown shoots (Figure 4.B), took about 6-8 days. The shoot then grew to maximum size with light green color and unopened leaves (Figure 4.C), and continued by the leaves development that lasts 16-18 days. The leaves mature as young-bright green leaves open (phase 3) in 2-3 days (Figure 4.D). The duration of shoot development (phase 0-3) lasts 24-29 days.

\section{Inflorescence emergence phase (phase 5)}

The inflorescence emergence phase $(\mathrm{BBCH}$ phase 5) started with swellings on the axilary buds indicating an enlargement of apical meristem (Figure 4.E). The swelled branches soon developed into flower buds in a series of panicle shaped inflorescences. Flower buds continued to develop to purple to cream petal. The end of phase 5 was marked by the bloating of the flower buds, ready to bloom. The duration of inflorescence emergence from bud appearance until the flower buds are ready to bloom ranges from 7-9 days.
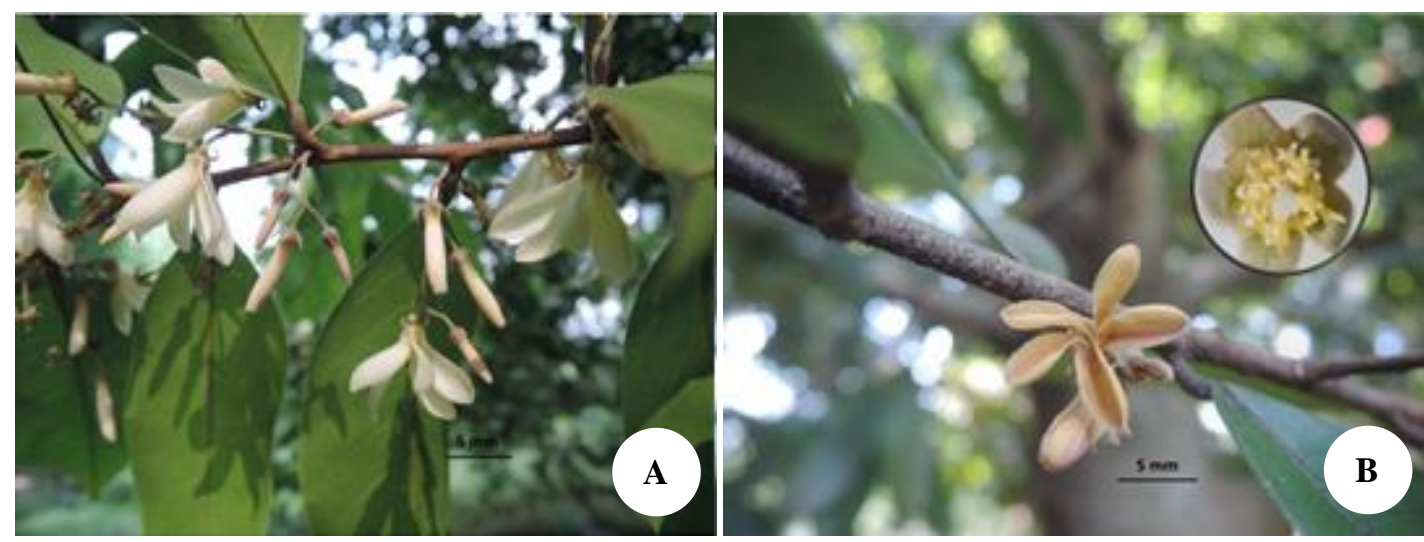

Figure 1. Flower of Vatica venulosa. A. Inflorescence at the end of a twig, B. Full bloom and anthesis
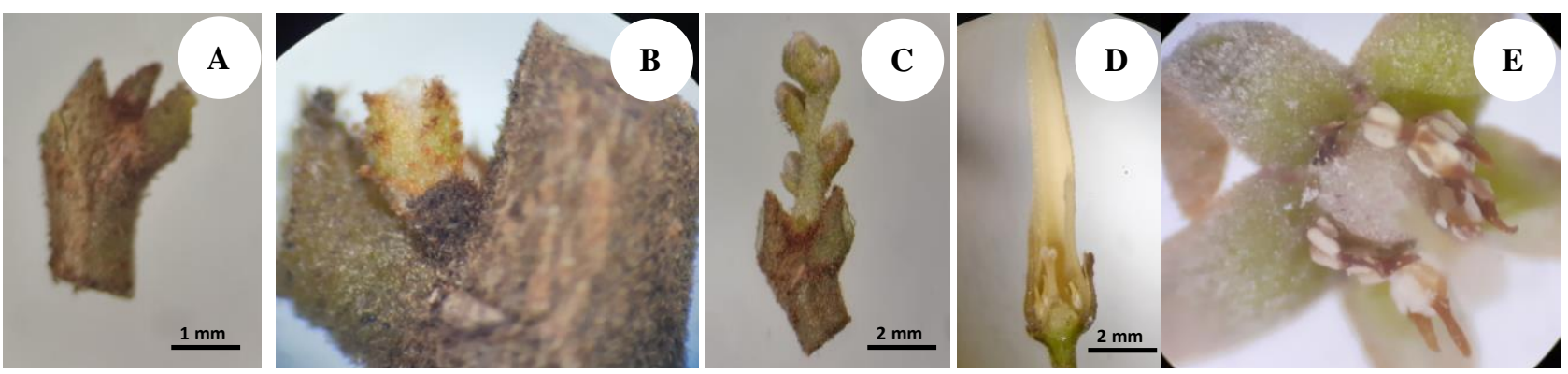

Figure 3. Flower development of Vatica venulosa phases 3-6. A. Leaf buds (phase 3), B. Flower buds (phase 5), C. Inflorescences (phase 5), D. Longitudinal dissection of a flower bud before blooming (phase 5), E. Flowers with all petals have fallen, anthers still attached (phase 6) 

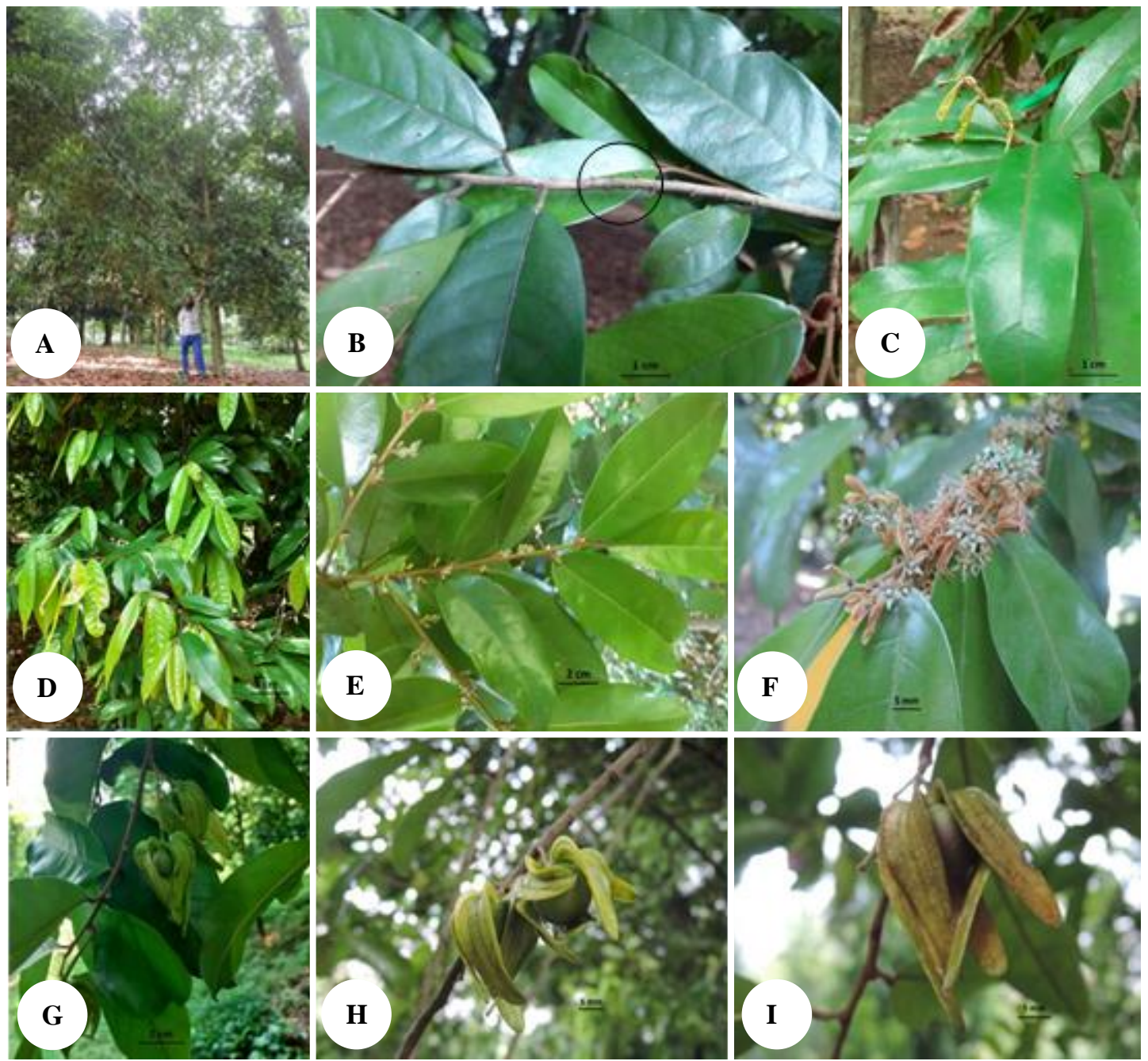

Figure 4. Flower and fruit development phase of Vatica venulosa in phases 0-9. A. Research plant V. venulosa, B. Shoot development (phase 0), C. Shoot development (phase 1), D. Leaf development (phase 3), E. Inflorescence emergence (phase 5), F. Flowering (phase 6), G. Fruit formation (phase 7), H. Fruit and seed maturity (phase 8), I. Fruit aging (phase 9). In the circle of picture B is the swelling of the tissue/protrusion of the shoot candidates)

\section{Development of fruit phase (phase 7)}

The fruit development phase (BBCH phase 7) began with the development of flower petals from a dull green color with a rough texture, a horizontal position, then the flower petals that function as a protector of the fruit (wings) continued to develop with the position of the petals bent, light green color, shiny, smooth texture, and until the petals were the maximum size. After the maximum size of the petals, the fruit will grow to $90 \%$ of the maximum size with green petals and green fruit (Figure 4.G). The development of fruit phase takes 85-88 days, the longest phase compared to other phases.

\section{Maturity of fruit and seed phase (phase 8)}

The fruit maturation phase (BBCH phase 8) started from the maximum size of the fruit petals (wings), the maximum size of the fruit (Figure 4.H) until the fruit was mature and ready to be harvested. In this phase the wings and pericarp turned from Green Group (GG) 143 B-C, then Yellow Green Group (YGG) 152 A-B, and finally Green
Orange Group (GOG) 175 A-C. The fruit maturation takes 18-20 days.

\section{Fruit senescencelfallen fruit phase (phase 9)}

The fruit senescence phase (BBCH phase 9) is the last phase in the flower to fruit development phase. This phase was characterized by wings and pericarp that turned to Green Orange Group (GOG) 164-165 C or drying and finally the fruits fell off (Figure 4.I). The duration of the fruit senescence process ranges from 3-4 days.

The development of flower buds into blooms on the sampled trees resulted in the number of inflorescences was 4 , the flower length ranged $1.32-1.47 \mathrm{~mm}$, the flower width ranged $0.25-0.36 \mathrm{~mm}$, the number of flowers bloomed ranged 0-6 flowers per inflorescence. The development of flower buds until the flower bloomed took between 7-9 days, and the loss of flower buds was very high, reaching between 40-97.5\%. Lima (2020) states that at the end of the dry season $80 \%$ of leaf shoots develop on woody species. 
The micro climatic conditions during the experiment were as follows: the average minimum temperature was $22.42{ }^{\circ} \mathrm{C}$ and the maximum was $32.10{ }^{\circ} \mathrm{C}$. The highest monthly rainfall reached $552.80 \mathrm{~mm}$ and the lowest was $16.41 \mathrm{~mm}$ per month. The minimum air humidity was $74.43 \%$ and the maximum was $89.21 \%$ (BMKG 2020). Temperature, humidity and duration of radiation greatly affect the vegetative and generative growth of plants in lowlands and submontane (Lima 2020). Winarni et al. (2016) also commented that climate change affects the flowering and fruiting time of Dipterocarpaceae in the forest.

\section{Pollination system}

The bagged flower buds were shed in 5-9 days after bagging, with blackish brown petals, indicating that the flower buds did not develop normally possibly due to too thick bagging materials (Figure 5.A). Of 170 sampled flower buds, none were successfully bloomed or were pollinated (Figure 5.B). Therefore the information to determine pollination system was inadequate. Several nymph Thrips sp. (Thysanoptera: Thripidae) with white color, $1-1.5 \mathrm{~mm}$ in size (Figures 6.C, 6.D) were found foraging the flowers, and some of them carried pollen load, although the pollen was not identified to be belongs to $V$. venulosa.

\section{Fruit and seeds}

The percentage of blooming flowers ranged 32.3-37.9 $\%$, indicating that most of flower buds did not develop fully into mature flower. Flower dropped (after blooming) was very high ranged 83.63-92.92\%. Fruit set was determined as the proportion of blooming flowers that develop into fruits, ranged $10.9 \%-12.6 \%$.

Based on the color of the wings and pericarp the fruit maturity of $V$. venulosa (BBCH phases 8 and 9) was divided into four categories (Figure 6). The first category (Figure 6.A) with fruit color of Green Group 143 B-C is characterized with cone shape and right twisted wings, with rough and shiny texture, the pointed wings are stiff/thick and flexible/thin. The second category (Figure 6.B) of Yellow Green Group 152 A-B fruit is characterized with cone shape and right twisted wings, rough and shiny texture, the lancet shape wings are stiff/thick and flexible/thin. The third category (Figure 6.C) of Green Orange Group 175 A-C fruit with the right-twisted winged cone, rough and shiny, the wing is lancet, stiff/thick and flexible/thin wings. The fourth category (Figure 6.D) of Green Orange Group 164-165 C fruit with right-twisted winged cone, coarse and dull with lancet wing, and flexible/thin wings. Based on the color of the wings and pericarp, the fruit maturity stages of $V$. venulosa took $96 \pm 2$ days after anthesis (DAA) to reach maturity stage $1,101 \pm 3$ DAA for maturity stage 2, 106 \pm 3 DAA for maturity stage 3 , and $110 \pm 3$ DAA for maturity stage 4 (Table 3 ). $V$. venulosa has five wings with three categories i.e. long (> $35 \mathrm{~mm})$, medium $(25.01-35.00 \mathrm{~mm})$ and short $(<25.00$ $\mathrm{mm}$ ) with the proportion of long $27.75 \%$, medium $57 \%$, and short $15.25 \%$ short.

Fruit weight, fruit diameter and seed length vary between maturity stages, but not seed weight, seed diameter and fruit length. The fruit weight and dimension tend to be lower as the fruits mature, which could be due to declining moisture content (Table 4). V. venulosa has fruit weight of $1.55 \pm 0.41 \mathrm{~g}$, diameter of $21.19 \pm 2.33 \mathrm{~mm}$, and a fruit length of $32.37 \pm 6.71 \mathrm{~mm}$. Seed weight of $V$. venulosa was $1.12 \pm 0.33 \mathrm{~g}$, diameter $12.54 \pm 1.43 \mathrm{~mm}$, and length $14.69 \pm 1.94 \mathrm{~mm}$ (Table 4). The seed shape is round-oval, with pericarp colors ranging from Green Group (GG) 143 A-B, Yellow Green Group (YGG) 152 A-B, Green Blue Group (GBG) N199 A-B, and Blue Green Group (BGG) 200 A-B. The pericarp is coarse, hairy with a dull color on the young seeds and has a fine, hairy, smooth and shiny texture on the mature seeds. The tip of the seed is pointed with a pistil still attached (Figure 7).

Table 3. Fruit maturity stages related to the color of the wings and the pericarp

\begin{tabular}{lcccc}
\hline Tree & $\begin{array}{c}\text { Maturity level 1 } \\
\text { (DAA) } \pm \text { SD }\end{array}$ & $\begin{array}{c}\text { Maturity level 2 } \\
(\text { DAA) } \pm \text { SD }\end{array}$ & $\begin{array}{c}\text { Maturity level 3 } \\
(\text { DAA }) \pm \text { SD }\end{array}$ & $\begin{array}{c}\text { Maturity level 4 } \\
\text { (DAA) } \pm \text { SD }\end{array}$ \\
\hline 1 & $94.35 \pm 1.73$ & $98.79 \pm 1.62$ & $103.89 \pm 1.23$ & $107.50 \pm 1.90$ \\
2 & $98.05 \pm 1.79$ & $103.76 \pm 1.30$ & $109.19 \pm 1.38$ & $112.53 \pm 1.36$ \\
Average & $96.20 \pm 2.62$ & $101.29 \pm 3.49$ & $106.55 \pm 3.73$ & $110.06 \pm 3.62$ \\
\hline
\end{tabular}

Note: DAA: day after anthesis

Table 4. Fruit and seed characteristics of Vatica venulosa

\begin{tabular}{|c|c|c|c|c|c|c|}
\hline \multirow{2}{*}{ Color } & \multicolumn{2}{|c|}{ Weight $(g) \pm$ SD } & \multicolumn{2}{|c|}{ Diameter $(\mathrm{mm}) \pm \mathrm{SD}$} & \multicolumn{2}{|c|}{ Length $(\mathrm{mm}) \pm \mathrm{SD}$} \\
\hline & Fruit & Seed & Fruit & Seed & Fruit & Seed \\
\hline GG 143 B-C and GG 143 A-B & $1.78^{\mathrm{a}} \pm 0.36$ & $1.16 \pm 0.25$ & $21.47^{\mathrm{ab}} \pm 2.17$ & $12.67 \pm 1.31$ & $33.41 \pm 7.32$ & $15.82^{\mathrm{a}} \pm 2.08$ \\
\hline YGG 152 A-B and YGG 152 A-B & $1.50^{\mathbf{b c}_{ \pm}} \stackrel{.33}{ }$ & $1.03 \pm 0.29$ & $20.15^{\mathbf{b}} \pm 2.07$ & $12.14 \pm 1.35$ & $29.00 \pm 6.97$ & $13.67^{b} \pm 1.78$ \\
\hline GOG 175 A-C and GBG N199 A-B & $1.66^{\mathbf{a b}^{\mathbf{b}}} \pm 0.46$ & $1.27 \pm 0.42$ & $20.62^{\mathbf{b}} \pm 1.39$ & $13.02 \pm 1.59$ & $34.44 \pm 2.66$ & $15.27^{\mathrm{a}} \pm 1.73$ \\
\hline GOG 164-165 C and BGG 200 A-B & $1.27^{\mathfrak{c}} \pm 0.31$ & $1.04 \pm 0.29$ & $22.51^{\mathrm{a}} \pm 2.87$ & $12.33 \pm 1.40$ & $32.63 \pm 7.78$ & $13.98^{b} \pm 1.38$ \\
\hline$P$ value & 0.0003 & 0.0608 & 0.0062 & 0.2188 & 0.0559 & 0.0004 \\
\hline
\end{tabular}

Note: GG: Green Group; YGG: Yellow Green Group; GOG: Green Orange Group; GBG: Green Blue Group; BGG: Blue Green Group 

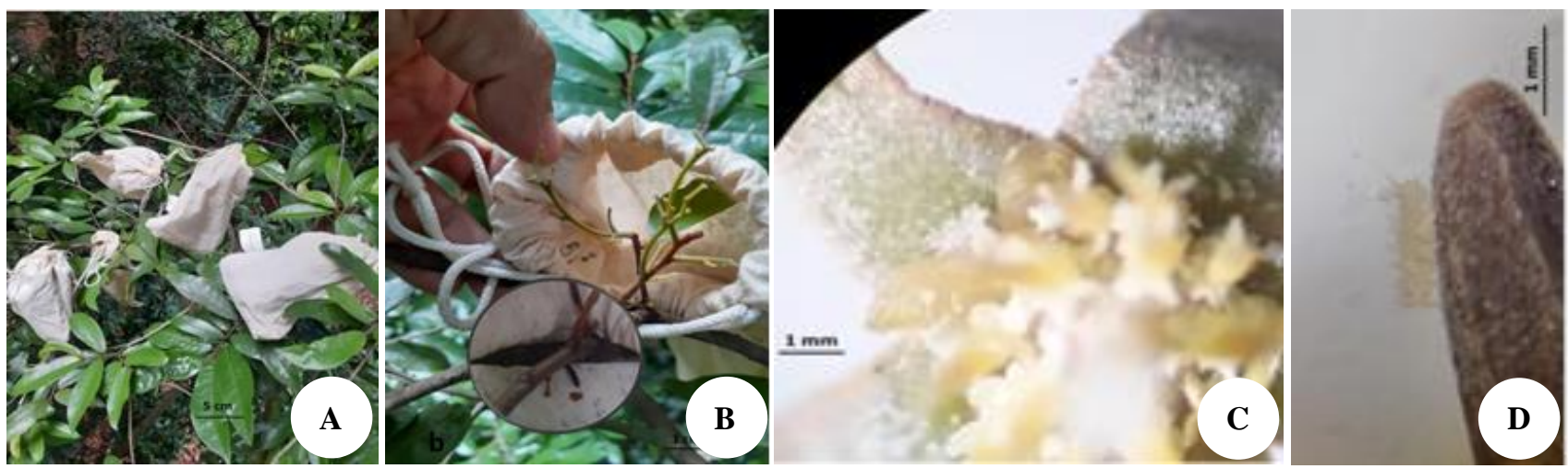

Figure 5. Bagging of the flower buds. A. Thick cloth bags, B. No flowers developed into fruit, C. Thrips sp. nymphs carrying pollen, D. Thrips sp. nymphs visiting the flower buds

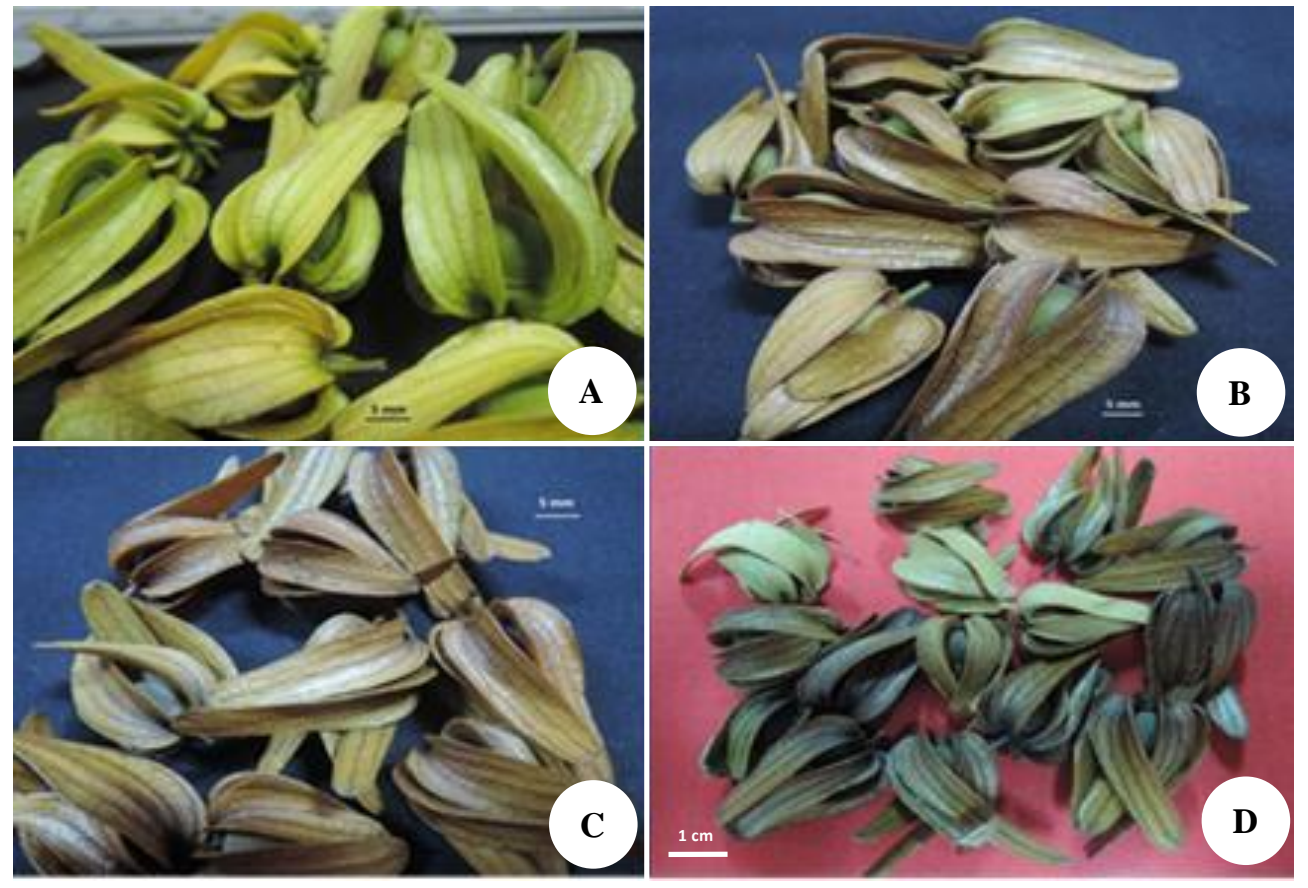

Figure 6. The degree of fruit maturity of Vatica venulosa based on the color of the wings and seed pericarp. A. Green Group 143 B-C, B. Yellow Green Group 152 A-B, C. Green Orange Group 175 A-C, D. Green Orange Group 164-165 C
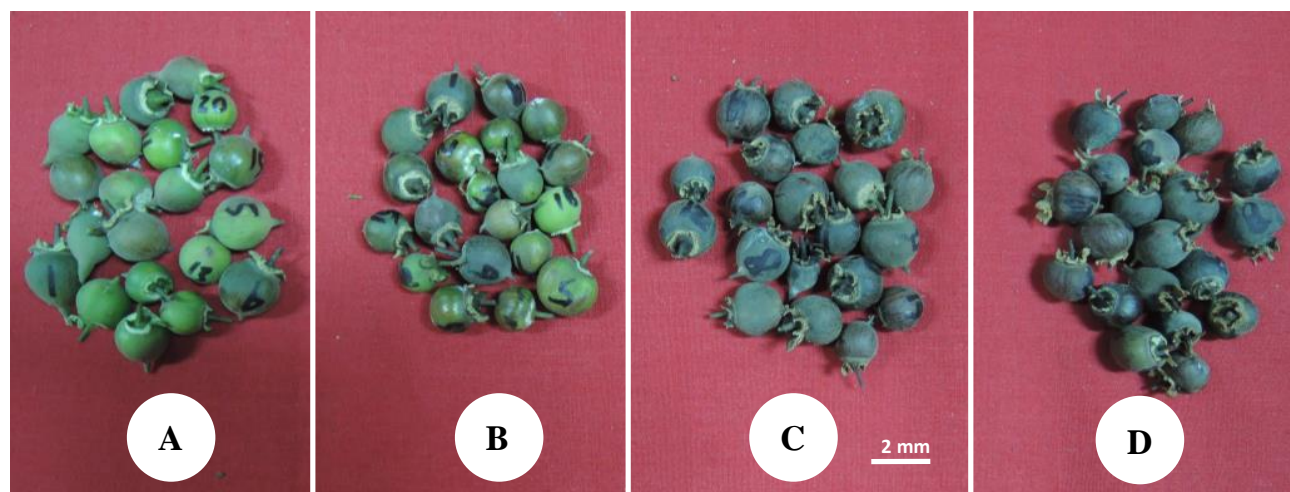

Figure 7. Vatica venulosa seed maturity. A. Green Group 143 A-B, B. Yellow Green Group 152 A-B, C. Green Blue Group N199 A-B, D. Blue Green Group 200 A-B 
Seeds for conservation need to be harvested at the physiological maturity to obtain highest quality. Seed germination capacity (GC) and vigor index (VI) are commonly used variables for seed viability and vigor respectively. The GC and IV of $V$. venulosa seed were highest (78.75-81.25\%, and 23.75-27.50\% respectively) at maturity stage 3 (Figure 8 ), and declined at stage 4 . The data indicated that physiological maturity of $V$. venulosa seeds was reached when the fruit was between $101 \pm 3$ DAA-106 \pm 3 DAA, when the wings and pericarp were of YGG 152 A-B to GOG 175 A-C and GBG N199 A-B. At that maturity stage the maximum growth potential (MGP) was also at the highest (87.5-93.75\%), while the seed moisture content (MC) has lowered (41.42-47.94\%). Dipterocarps seed are recalsitrant, thus, the declining GC, VI and MGP at maturity stage 4 indicated that seed deterioration has taken place. Therefore, seeds has to be collected when the color of the fruit wings has turned to yellow green or green orange.

\section{Seed structure}

At the early seed development of $V$. venulosa $(<20$ days) the endosperm is still a liquid (Figure 9.A, 9.B), indicating a nuclear type of endosperm development. At the later stage of development (> 50 days) the endosperm seemed to become selularised and the embryo with two cotyledons was formed (Figure 9.C). The embryo is located at the distal part of the fruit, i.e at the pistil end of the flower, suggesting that the ovule is orthotropous type.

When the fruit had reached its maximum size with green pericarp, the seed is determined as morphologically mature in which the important structure of the seed had been formed, i.e. the embryo comprises of cotyledons and embryo axis that is the axis of radicle and plumules (Figure 9.D). At this stage the cotyledon is still soft. The seed is at physiological maturity when the fruit has green orange pericarp. The embryo sac is fully filled with hard cotyledon and light green embryo axis indicating that accumulation of storage reserve has been completed (Figure 9.D, 9.F).

Vatica venulosa seed cotyledons are starch clumps based on the results of the biochemical analysis of $V$. venulosa seed showing the dominance of carbohydrates $(42.48 \%)$, whereas the other substances were in small quantities, such as $1.73 \%$ fat, $3.57 \%$ protein, and $1.0 \%$ ash with $51.23 \%$ seed moisture content.

\section{Discussion \\ Flower morphology}

The flowering season of Vatica venulosa in the Bogor Botanic Gardens was twice a year (sub annual). The 15year-old plants (number collection XXIV.A.235-two individuals) flowered between February-March and August-September, while the fruiting season was between June-July and January-February. Vatica venulosa that grow in the natural habitat of the Bangka-Belitung forest were fruiting in October 2020, so it was suspected that flowering occurred in June-July 2020 in Kehati Geosite Peramun Park, Protected forest (PF) Mount Tajam, PF Mount Bantan, Belitung Arsel Community Garden. The different time of flowering at the two location could be due to different environment and climate, and a more detail study on flowering season of $V$. venulosa at its natural habitat is required to clarify the flowering pattern of this spesies. This sub annual pattern also occurs in Vatica obovata and Dipterocarpus gracilis (Hartiningsih et al. 2019). V. yeechongii flowers in February-March (Suhaida et al. 2018), while Shorea spp flowers in March-June and August-November in Malaysia and India (Chen et al. 2018; Raju et al. 2011; Sasaki 2008). Winarni et al. (2016) stated that the minor flowering time of Dipterocarpaceae was March to July and the major flowering time was September-November in the Bukit Barisan Selatan National Park Forest (BBSNP), Sumatra.
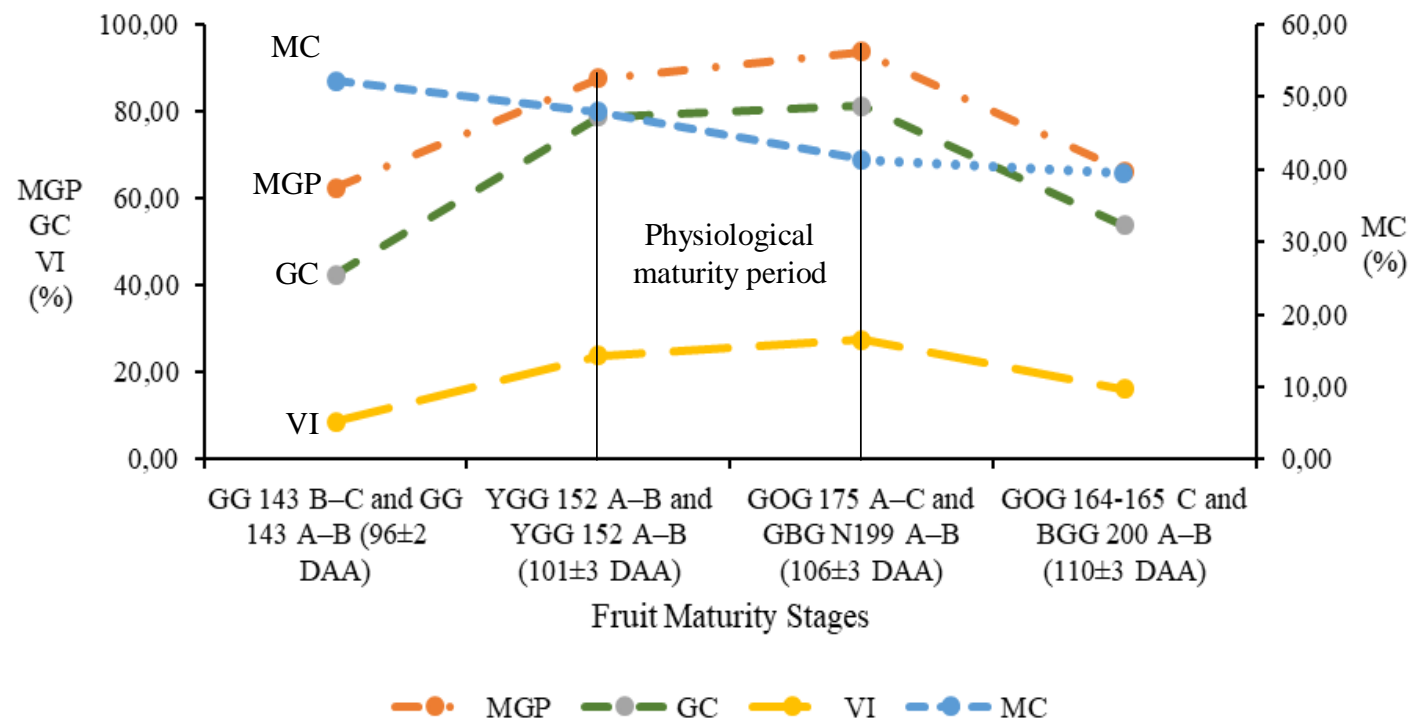

Figure 8. Determination of seed physiological maturity of Vatica venulosa based on the stage of fruit maturity stages 


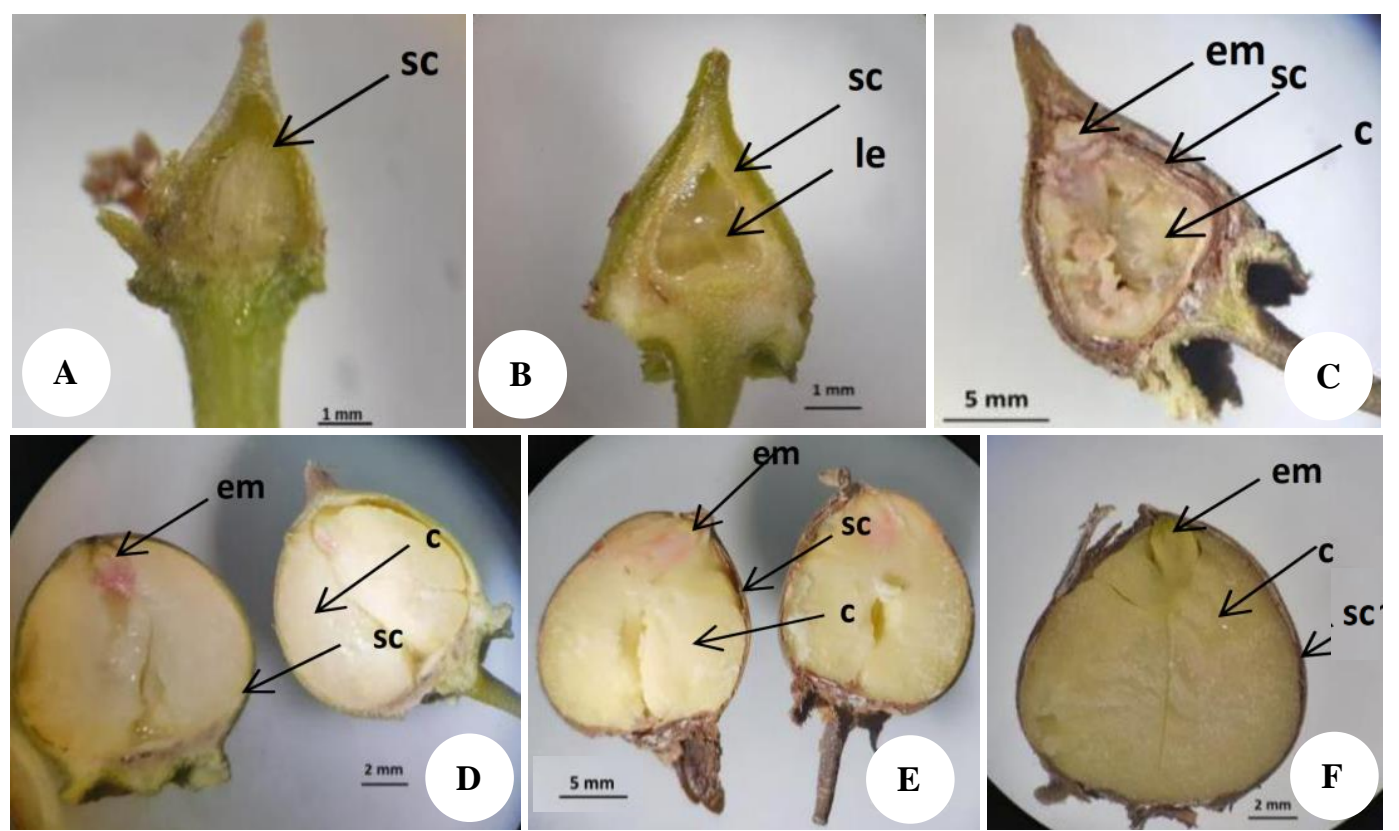

Figure 9 Vatica venulosa seed development. A. Young fruit, B. Ovule with liquid endosperm, C. Aborted young fruit, D. Green fruit at maximum size, E-F. Physiologically mature fruit; sc: seed coat, le: liquid endosperm, em: embryo, c: cotyledons

The inflorescences elongate and have several flowers arranged in panicles. Leaf buds were developed on the shoots of the leaves, then the buds open into young leaves. After the young leaves fully developed, then the inflorescences were initiated, which is indicated by the swelling of the meristems that developed from the axillary shoots. Shivaprasad et al. (2017) stated that Dipterocarpus indicus flowers are hermaphrodite, complete, flowers anthesis at 08:00 to 10:00 hours, ovary is superior, syncarpous, with three locules each containing two ovules arranged in placentation axile.

\section{Flower development}

Plant development from phase 0 to phase 3 lasts 24-29 days. The duration of flower development from bud appearance until the flower buds are ready to bloom ranges from 7-9 days. The fruit development phase is the longest phase compared to other phases. The period for fruit development ranges from 85-88 days. In this phase, fruit loss also often occurs due to the changes in the environment and plant mechanisms due to the competition for nutrients. The duration of the fruit maturation ranges from 18-20 days. The total duration of inflorescence emergence $(\mathrm{BBCH}$ phase 5$)$ to mature fruit $(\mathrm{BBCH}$ phase 8) ranges from 111-120 days. The duration of the fruit aging process ranges from 3-4 days, the total duration of inflorescence emergence (BBCH phase 5) to fruit loss (BBCH phase 9) ranges from 114-125 days. Flower initiation to fruit fall in $V$. lanceaefolia, Anisoptera scaphula, Dipterocarpus turbinatus, Hopea odorata takes 3-4 months (Borah and Dewi 2014; Hasnat et al. 2016), Shorea spp, V. najibiana 2-3 months (Chen et al. 2018; Ummul-Nazrah et al. 2018).
According to Azmy et al. (2016), flowering is influenced by the level of drought, temperature, photosynthetic activity, light intensity, high vegetation cover/plant canopy; when these factors were high flowering period may occur shorter, but this had to be combined with low humidity and rainfall. The flowering period and the flowering phenology of the Dipterocarpaceae are varied between different species.

\section{Pollination system}

Vatica venulosa is very likely a cross-pollinated plant, as indicated by flower structure in which the position of the pistil is higher/longer than the stamen; and also pollen was released prior to stigma being receptive (protandrous). Similarly, the pollination systems for Shorea maxwelliana, S. curtsii, S. acuminata, and Vatica yeechongii are cross pollination and Thrips are also pollinators of these plants (Masuda et al. 2013; Kondo et al. 2016; Kondo et al. 2016a; Kettle et al. 2011; Suhaida 2018).

\section{Fruit and seeds}

Vatica venulosa fruit has different maturity stages when it falls out. Therefore, harvesting time greatly affects the viability of the seeds produced. Physiological maturity determination is carried out to determine the right harvest time with maximum seed viability, vigor and relatively low seed moisture content. Masullo (2020) states that there are variations in fruit morphology from the genera Malvaceae, including the number of mericarp, the relationship between calyx and fruit, the number of seed per locule. $V$. venulosa has fruit set $13.17-16.15 \%$, while the research results of Keshavanarayan et al. (2015) revealed that the fruit set of Vateria macrocarpa (Dipterocarpaceae) with natural pollination was $22 \%$. Shivaprasad et al. (2017) stated that 
manual cross pollination resulted in $69.53 \%$ fruit sets. Identification of the effective pollinator and enhancing the population would be useful to improve fruit set.

Vatica venulosa has five wings with fruit length of $32.37 \pm 6.71 \mathrm{~mm}$ and weight of $1.55 \pm 0.41 \mathrm{~g}$. Physiological maturation period was at the age of $101 \pm 3$ DAA to $106 \pm 3$ DAA, with the characterictic wing and pericarp color of YGG 152 A-B to GOG 175 A-C and GBG N199 A-B. This was confirmed by Sasaki (2008), who revealed that Dipterocarp fruits generally have wings developed from the petals. The petals initially consist of five lobes. The number of wings that developed on mature fruit was five in Dryobalanops and Parashorea, three in Shorea, while Dipterocarpus, Hopea, Upuna, Anisoptera, Cotylelobium and Vatica developed two wings. The maturity of the fruit is indicated by drying wings from the tip to the base of the wings. The parts that dries out on the wings then become stiff facilitating the winged seeds (propagule) to disperse from the parent trees. In addition, mature Parashorea seeds are brown with sturdy-dark wings showing clear patches at the base of the wings. This is caused by the fruit moisture content decreasing during the maturation process, as indicated by the lower mature fruit weight compared with the unmatured.

\section{Seed structure}

As the fruit gets older, the cotyledons develop, enlarge until the fruit reaches physiologically maturity, harvesting maturity and eventually falls off with the lower level of seed moisture content. The cotyledons of $V$. venulosa are very large and dominate almost the entire seed. The cotyledons of the seeds are divided into two parts with the indicator line right in the middle of the seeds so that when they are opened and taken, they will be divided easily. $V$. venulosa fruit is categorized as non endospermous because the endosperm is depleted for development, maturation of fruit and seeds.

Fruit development in plants begins with the development of cotyledons which are initially liquid endosperm and fill the cavity of the embryo sac even after the seeds are fully mature. At the immature stage, the cotyledons are very small. This suggests that the outflow of food reserves from the endosperm to the cotyledons continues until the final stage of seed maturation. At the time of dispersal, the seeds reduce their moisture content by $70 \%$ or less based on dry weight ( $V$. venulosa MC $46 \%$ ). This development is used by plants to select seeds that mature well and germinate more quickly. The seed maturation process continues in the seeds of Dipterocarpaceae. According to Sasaki (2008) Dipterocarpaceae produces exalbuminous seeds which contain a small portion of endosperm, as food reserves are stored in the cotyledons. Dipterocarpus seeds have starch granules as a reserve substance. Among the Shorea subgroups, Rubroshorea seeds have starch granules as the main seed reserves, but the reserves in Rubroshorea, Eushorea, and Richetia are in their oil content. Parashorea has an abundant oil content in the cotyledons. Hopea odorata also has a high oil content, but other Hopea spp may have either high starch or oil contents, depending on the species. $V$. venulosa seed contain a dominant carbohydrate of $42.48 \%$ and a little fat of $1.73 \%$.

\section{ACKNOWLEDGEMENTS}

We would like to thank the Director of the Research Center for Plant Conservation and Botanic Gardens-LIPI for the research facilities at the Seed Bank of Research Center for Plant Conservation and Botanic Gardens LIPIMillennium Seed Bank Partnership.

\section{REFERENCES}

Ashton P. 1998. Vatica venulosa. The IUCN Red List of Threatened Species 1998: e.T33458A9785745. DOI: 10.2305/IUCN.UK.1998.RLTS.T33458A9785745.en. 29 May 2019.

Azmy MM, Hashim M, Numata S, Hosaka T, Noor NSM, Fletcher C. 2016. Satellite-based characterization of climatic conditions before largescale general flowering events in Peninsular Malaysia. Sci Rep 6: 32329. DOI: $10.1038 /$ srep32329

BMKG (Badan Meteorologi Klimatologi dan Geofisika). 2020. Data online pusat database BMKG. [Indonesian]

Borah M, Devi A. 2014. Phenology, growth and survival of Vatica lanceaefolia Bl.: A critically endangered tree species in a moist tropical forest of Northeast, India. Trop Plant Res 1 (3): 1-12.

Chechina M, Hamann A. 2019. Climatic drivers of dipterocarp massflowering in South-East Asia. Journal of Tropical Ecology. 35:108117. https://doi.org/10.1017/S0266467419000087

Chen YY, Satake A, Sun IF, Kosugi Y, Tani M, Numata S, Hubbel SP, Fletcher C, Supardi MNN, Wright SJ. 2018. Species-specific flowering cues among general flowering Shorea species at the Pasoh Research Forest, Malaysia. J Ecol 106: 586-598. DOI: 10.1111/13652745.12836

Daisuke H, Tanaka K, Jawa KJ, Ikuo N, Katsutoshi S. 2013. Rehabilitation of degraded tropical rainforest using dipterocarp trees in Sarawak, Malaysia. International Journal of Forest Research 683017: 1-11. http://dx.doi.org/10.1155/2013/683017

Djuita NR. 2016. Biologi Tanaman Kapulasan (Nephelium ramboutan-ake (Labill.) Leenh. [Dissertation], IPB University, Bogor. [Indonesian]

El Taguri HMA, Latiff A. 2016. Ecology and distribution of Vatica L. (Dipterocarpaceae) in Peninsular Malaysia. Malay Nat J 68 (3): 5-11.

Hasnat GNT, Hossain MK, Hossain MA. 2016. Flowering fruiting and seed maturity of common plantation tree species in Bangladesh. J Biosci Agric Res 07 (01): 583-589. DOI: 10.18801/jbar.070216.70

Hartiningsih D, Andaryani N, Winarni NL. 2019. Phenological Pattern and Community Structure of Dipterocarpaceae in Bukit Barisan Selatan National Park, Lampung. In: Garkoti CS, Bloem VJS, Fule ZP, Semwal LR. Tropical Ecosystems: Structure, Functions and Challenges in the Face of Global Change. Springer Nature Singapore Pte Ltd. DOI: 10.1007/978-981-13-8249-9

Keshavanarayan P, Rajkumar K, Sivaram V. 2015. Phenology and reproductive ecology of Vateria macrocarpa B. L. Gupta (Dipterocarpaceae) a critically endangered tree species of Western Ghats, Kerala, India. IJABR 5 (4): 402-410.

Kettle CJ, Maycock CR, Ghazoul J, Hollingsworth PM, Khoo E, Sukri RSH, Burslem DFRP. 2011. Ecological implications of a flower size/number trade off in tropical forest trees. PLoS ONE 6 (2): e16111. DOI: 10.1371/journal.pone.0016111

Kurten EL, Bunyavejchewin S, Davies SJ. 2017. Phenology of dipterocarp forest with seasonal drough: Insights into the origin of general flowering. J Ecol 106: 126-136. DOI: 10.1111/1365-2745.12858

Kondo T, Otani T, Lee SL, Tani N. 2016. Pollination system of Shorea curtisii, a dominant species in hill dipterocarp forest. J Trop For Sci 28: 318-323.

Kondo T, Nishimura S, Tani N, Ng Siong KT, Lee SL, Muhammad N, Okuda T, Tsumura Y, Isagi Y. 2016a. Complex pollination of a tropical Asian rainforest canopy tree by flower-feeding thrips and thrips-feeding predators. Am J Bot 103 (11): 1-9. DOI: 10.3732/ajb.1600316 
Lima MS, Junior GAD. 2020. Phenology and dispersal syndrome of woody species in deciduous forest fragments of the Pantanal in Mato Grosso do Sul State, Brazil. Acta Bot Bras 34 (2): 312-326. DOI: 10.1590/0102-33062019abb0353

Masuda S, Tani N, Ueno S, Lee SL, Muhammad N, Kondo T, Numata S, Tsumura Y. 2013. Non-density dependent pollen dispersal of Shorea maxwelliana (Dipterocarpaceae) revealed by a bayesian mating model based on paternity analysis in two synchronized flowering seasons. PLoS ONE 8 (12): e82039. DOI: 10.1371/ journal.pone.0082039

Masullo FA, Siqueira SFH, Barros CF, Bovini MG, Toni KLG. 2020 Fruits of neotropical species of the tribe Malveae (MalvoideaeMalvaceae): macro and micromorphology. Acta Bot Bras 34 (2): $301-$ 311. DOI: 10.1590/0102-33062019abb0293

Meier U. 2018. Growth stages of mono and dicotyledonous plants (BBCH Monograph). German. Julius Kühn-Institut (JKI) Bundesforschungsinstitut für Kulturpflanzen (Federal Research Centre for cultivated Plants) Erwin-Baur-Straße 2706485 Quedlinburg. DOI: 10.5073/20180906-074619

POWO (Plants of the World Online). 2020. Vatica venulosa Blume. Royal Botanic Gardens Kew Science.

Raju AJS, Ramana KV, Chandra PH. 2011. Reproductive ecology of Shorea roxburghii G. Don (Dipterocarpaceae), an Endangered semievergreen tree species of peninsular India. J Threaten Taxa 3 (9) 2061-2070. DOI: 10.11609/JoTT.o2763.2061-70
Ronse De Craene L, Iwamoto A, Bull-Herenu K, Dos Santos P, Luna JA, Farrar J. 2014. Understanding the structure of flowers-The wonderful tool of floral formulae: A response to Prenner \& al. TAXON. 63 (5): 1103-1111. DOI: $10.12705 / 635.35$

Sasaki S. 2008. Physiological characteristics of tropical rain forest tree species: a basis for the development of silvicultural technology. Proc Jpn Acad Ser B Phys Biol Sci 84 (2): 31-57. DOI: 10.2183/pjab/84.31

Shivaprasad D, Kumar CNP, Somashekar RK, Nagaraja BC. 2017. Reproductive biology of Dipterocarpus indicus Bedd. An endangered species from Western Ghats, India. Proceeding of the International Academy and Ecology and Environmental Sciences 7 (4): 97-105.

Suhaida M, Haron NW, Chua LSL, Chung RCK. 2018. Floral Phenology and Pollination Biology of Vatica yeechongii (Dipterocarpaceae). J Trop For Sci 30 (4): 497-508. DOI: 10.26525/jtfs2018.30.4.497508 Ummul-Nazrah AR, Mohd Hairul MA, Imin K, Kiew R, Ong PT. 2018. Vatica najibiana (Dipterocarpaceae), a new species from limestone in Peninsular Malaysia. PhytoKeys 98: 99-106. DOI: 10.3897/phytokeys.98.23903

Winarni NL, Kurniasari DW, Hartiningtias D, Nusalawo M, Sakuntaladewi N. 2016. Phenology, climate, and adaptation: How does dipterocarps respond to climate?. Indonesian Journal of Forestry Research. 3(2): 129-141. DOI: 10.20886/ijfr.2016.3.2.129-141 